46. Centers for Disease Control and Prevention. Outbreaks of pneumococcal pneumonia among unvaccinated residents in chronic-care facilitiesMassachusetts, October 1995, Oklahoma, February 1996, and Maryland, May-June 1996. MMWR 1997;46:60-62.

47. McNeeley DF, Lyons J, Conte S, Labowitz A, Layton M. A cluster of drug-resistant Streptococcus pneumoniae among nursing home patients. Infect Control Hosp Epidemiol 1998;19:476-477.

48. Centers for Disease Control and Prevention. Surveillance for penicillinnonsusceptible Streptococcus pneumoniae-New York City, 1995. MMWR 1997;46:297-299.

49. Centers for Disease Control and Prevention. Prevalence of penicillinresistant Streptococcus pneumoniae-Connecticut, 1992-1993. MMWR 1994;43:216-217,223.

50. Butler JC, Hofmann J, Cetron MS, Elliott JA, Facklam RR, Breiman RF The continued emergence of drug-resistant Streptococcus pneumoniae in the United States: an update from the Centers for Disease Control and Prevention's Pneumococcal Sentinal Surveillance System. I Infect Dis 1996;174:986-993.

51. Centers for Disease Control and Prevention. Recommendations of the Immunization Practices Advisory Committee. Pneumococcal polysaccharide vaccine. JAMA 1989;261:1265-1267.

52. US Public Health Service. Healthy People 2000 Review, 1995-96. Washington, DC: US Department of Health and Human Services, Public Health Service; 1996

53. Beck-Sague C, Villarino E, Giuliano D, Welbel S, Latts L, Manangan LM, et al. Infectious diseases and death among nursing home residents: results of surveillance in 13 nursing homes. Infect Control Hosp Epidemiol 1994;15:494-496.

54. Beck-Sague C, Banerjee S, Jarvis WR. Infectious diseases and mortality among US nursing home residents. Am J Public Health 1993;83:1739-1742.

55. Kunin CM. Care of the urinary catheter. In: Kunin CM, ed. Detection, Prevention and Management of Urinary Tract Infections. Philadelphia, PA: Lea and Febiger; 1972.

56. Wong ES. Guideline for prevention of catheter-associated urinary tract infections. Am I Infect Control 1983;11:28-31.
57. Nicolle LE, Muir P, Harding GK, Norris M. Localization of urinary tract infection in elderly, institutionalized women with asymptomatic bacteriuria. J Infect Dis 1988;157:65-70.

58. Nicolle LE, Brunka J, McIntyre M, Murray D, Harding GK. Asymptomatic bacteriuria, urinary antibody, and survival in the institutionalized elderly. J Am Geriatr Soc 1992;40:607-613.

59. Nordenstam GR, Brandberg CA, Oden AS, Svanborg Eden CM, Svanborg A. Bacteriuria and mortality in an elderly population. $N$ Engl J Med 1986;314:1152-1156.

60. Kunin CM, Douthitt S, Dancing J, Anderson J, Moeschberger M. The association between the use of urinary catheters and morbidity and mortality among elderly patients in nursing homes. Am J Epidemiol 1992;135:291-301.

61. Garner JS, Favero MS. CDC Guideline for handwashing and hospital environmental control, 1985. Infect Control 1986;7:231-243.

62. Larson EL. APIC guideline for handwashing and hand antisepsis in health care settings. Am I Infect Control 1995;23:251-269.

63. Thompson BL, Dwyer DM, Ussery XT, Denman S, Vacek P, Schwartz B. Handwashing and glove use in a long-term-care facility. Infect Control Hosp Epidemiol 1997;18:97-103.

64. Crossley K, SHEA Long-Term Care Committee. Vancomycin-resistant enterococci in long-term-care facilities. Infect Control Hosp Epidemiol 1998;19:521-525.

65. Nicolle LE, Bentley D, Garibaldi R, Neuhaus E, Smith P. Antimicrobial use in long-term-care facilities. Infect Control Hosp Epidemiol 1996;17:119-128.

66. Smith PW, Seip CW, Schaefer SC, Bell-Dixon C. Microbiologic survey of long-term care. 36th Annual Meeting of the Infectious Diseases Society of America, November 1998; Denver, CO. Abstract 6435a.

67. Mylotte JM. Antimicrobial prescribing in long-term care facilities: prospective evaluation of potential antimicrobial use and cost indicators. Am J Infect Control 1999;27:10-19.

68. Zimmer JG, Eggert GM, Treat A, Brodows B. Nursing homes as acute care providers. A pilot study of incentives to reduce hospitalizations. $J$ Am Geriatr Soc 1988;36:124-129.

\title{
Effectiveness of a Manual Disinfection Procedure in Eliminating HCV From Experimentally Contaminated Endoscopes
}

\section{Gina Pugliese, RN, MS Martin S. Favero, PhD}

Transmission of hepatitis $\mathrm{C}$ virus (HCV) through endoscopy has been reported, but the implications as a public health concern remain controversial. Some hospital hygienists believe that extraordinary means of cleaning and disinfection must be used on instruments of endoscopy after they are exposed to patients with $\mathrm{HCV}$ infection. Others believe that current cleaning and disinfection procedures are conservative enough and do not have be modified to eliminate the risk of $\mathrm{HCV}$ transmission. Chanzy and coinvestigators from France conducted a study that investigated the degree to which a thorough manual cleaningwashing-disinfection procedure can decontaminate all channels of a flexible submersible endoscope experimentally contaminated with HCV. To assess the accuracy of the method currently in use, the initial investigation focused on sampling effectiveness. Nine endoscopes were contaminated with hightiter HCV-positive plasma and flushed with $150 \mathrm{~mL}$ of sampling solution (distilled water) before disinfection. To assess the effectiveness of the disinfection procedure, the following sequence was performed on another 10 endoscopes: inoculation, disinfection, and sampling. After concentration, residual viruses were detected by means of RNA amplification with commercial assays.

The study showed that sampling alone can reduce viral titer to onefourth its original value. Within the limits of this method, HCV RNA was never detected by means of polymerase chain reaction after disinfection, whereas all internal amplification controls were positive. This reduction to less than $1 / 100,000$ of original titer exceeds the criterion expected for the virucidal activity of disinfectants.

The authors conclude that the results of this in vitro experiment provided evidence that patient-to-patient endoscopic transmission of $\mathrm{HCV}$ can be reduced, if not eliminated, with the current mechanical cleaning-washingdisinfection procedure.

FROM: Chanzy B, Duc-Bin DL, Rousset B, Morand P, Morel-Baccard C, Marchetti B, et al. Effectiveness of a manual disinfection procedure in eliminating hepatitis $\mathrm{C}$ virus from experimentally contaminated endoscopes. Gastrointest Endosc 1999; 50:147-151 